\title{
THE "E TRIANGLE": EMPLOYMENT, EMPLOYEE AND EMPLOYER IN THE EUROPEAN UNION
}

\author{
Liviana Andreea Niminet \\ "Vasile Alecsandri" University of Bacau \\ liviananiminet@yahoo.com
}

\begin{abstract}
One of the biggest forces of the European Union is its people, people living and working within this Union. This stands not only for the European Union but for every state, as it is well known that people are the ones that can make a state great or poor. For this reason, the matters regarding labor are a continuous concern both for European Union common institutions as well as for every individual state of the European Union. The main interest, on both sides, is to ensure the best for every part involved in labor process because this means, in the end, added value for everyone. The article focuses on the realities as well as on the expectations regarding the labor field highlighting the most preeminent aspects of the so called "E triangle": employment, employee and employer starting with the most needed definition for each and every one of the above going towards even to proposing remedies for the "spots" needing improvement.
\end{abstract}

\section{Keywords}

employment; employee; employer; labor; European Union

\section{JEL Classification}

J08; K31

\section{Introduction}

Employee is generally defined as "an individual who works part-time or full-time under a contract of employment, whether oral or written, express or implied, and has recognized rights and duties. Also called worker." while the employer is a "legal entity that controls and directs a servant or worker under an express or implied contract of employment and pays (or is obligated to pay) him or her salary or wages in compensation".

Employment, on the other hand, has more meanings: "1 an act or instance of employing someone or something; 2 the state of being employed; 3 an occupation by which a person earns a living; work; business. 4 the total number of people gainfully employed or working. 5 an activity or the like that occupies a person's time".

Although all of the above definitions are linguistically correct none of them comprises the true dimensions and importance of these three words.

No matter where we stand everything revolves around the "E triangle" because, virtually it all comes done to work.

Employment, employee and employer matter importance was recognized by most of the states. European Union has developed, back in 1997, a strategy called The European employment strategy (EES). It establishes a set of common objectives and targets for employment policy and mainly aims to create more and better jobs throughout the EU. 


\section{Employment matters - European Union vision}

Employment issues are a continuous concern for the European Union, as we stated. Now it is visible in the Europe 2020 growth strategy whilst being implemented through the European semester, the process promoting close policy coordination of EU Member States and EU Institutions.

On a closer look, the implementation of the EES (supported by the work of the Employment committee) mainly supposes four steps of the European Semester:

- Employment guidelines are priorities and targets for employment policies that are first proposed by the Commission, then agreed by national governments and finally, adopted by the EU Council.

- The Joint employment report (JER) is based on three important milestones: the assessment of the employment situation in Europe; the implementation of the Employment Guidelines and an assessment of the Scoreboard of key employment and social indicators. JER is published by Commission and then adopted by the EU Council.

- National Reform Programmers (NRPs) are submitted by national governments and afterwards analyzed by the Commission for compliance with Europe 2020.

- Based on the assessment of the NRPs the Commission publishes a series of Country reports, both for analyzing Member States' economic policies and also for issuing specific recommendations for each member state.

\section{The Employment Package}

This Package was launched in April 2012 as a set of policy documents looking into how EU employment policies interact with a number of other policy areas all with the aim of smart, sustainable and inclusive growth. It identifies the EU's biggest job potential areas and the most effective ways for EU countries to create more jobs by proposing measures that target three directions: supporting job creation; restoring the dynamics of labor markets and improving EU government.

Job creation is supported by: Stepping up job creation across the economy; reducing the tax on labor while ensuring fiscal sustainability; promoting and supporting self employment, social enterprises and business start-ups; transforming informal or undeclared work into regular employment; boosting 'take home' pay; modernizing wage-setting systems to align wages with productivity developments; Harnessing the potential of job-rich sectors: ICT, green economy, healthcare; Mobilizing EU funds for job creation by European Social Fund.

Restoring the dynamics of labor markets is ensured mainly by reforming labor markets. This means encouraging companies' internal flexibility to protect jobs in crisis times; encouraging decent and sustainable wages; making job transitions pay; reducing the labor market segmentation between those in precarious employment and those on more stable employment; anticipating economic restructuring; developing lifelong learning and active labor market policies; delivering youth opportunities and the youth employment package (see also youth unemployment analysis and youth 
action teams); reinforcing social dialogue and public employment services; Investing in skills and in the synergy between the worlds of education and work.

Improving EU Governance mostly means: Reinforcing coordination and multilateral surveillance in employment policy and Strengthening the link between employment policies and relevant financial instruments.

\section{Long term unemployment- three key steps}

One of the key employment challenges is addressing long-term. The European Commission is stepping up supporting Member States by giving them more specific policy guidelines.

The Commission has identified three key steps for dealing with long term unemployment:

1. encouraging the registration of long-term unemployed with an employment service;

2. providing each registered long-term unemployed with an individual in-depth assessment to identify their needs and potential at the very latest at 18 months of unemployment;

3. Offering a job integration agreement to all registered long-term unemployed at the very latest at 18 months.

Simplified access to support will lead to simplified and better access to support for those that are out of work for long periods of time.

The job integration agreement means a tailor-made plan that is meant to bring the long-term unemployed back to work. It can include, given the existing services in each Member State one or many from the following: mentoring, help with the job search, further education and training, support for housing, transport, child and care services or rehabilitation. Every long-term unemployed will have a single point of contact for accessing this support.

Member States are involved in an active commitment and partnership with employers, who should be more dedicated to finding a pathway back to work for the long-term unemployed.

\section{Labor law- the big picture}

Labor law defines one's rights and obligations as workers and employers.

EU labor law addresses two main areas:

- working conditions such as working hours, part-time and fixed-term work, posting of workers, and so on;

- informing and consulting workers about collective redundancies, transfers of companies, and so on.

The main objectives of EU policies and law on labor are to:

- achieve high employment as well as strong social protection,

- improve the living and working conditions,

- $\quad$ protect social cohesion.

From the very preamble of the Treaty on the Functioning of the EU is settled the EU aim: to promote social progress and improve the living and working conditions of the peoples of Europe.

On what labor law is concerned, the EU encourages policy initiatives of individual EU countries by setting minimum standards. In accordance with the article 153 of the 
Treaty EU adopts laws (directives) that establish minimum requirements for working and employment conditions, informing and consulting workers.

Besides the Directives, individual EU countries are free to provide higher levels of protection if they wish to. Let us take an example: European Working Time Directive entitles workers to 20 days' annual paid leave but many countries (Romania not included) have opted for a more generous right to the benefit of workers.

The EU adopts directives which member countries incorporate in national law and implement. This means that the national authorities (labor inspectorates and courts, for example) that enforce the rules.

When facing a dispute before a national court that raises a question of how to interpret an EU directive, the court can refer the issue to the Court of Justice of the EU. The European Court gives afterwards the national court the answers it needs to resolve the dispute.

The Commission makes sure that EU directives are incorporated into national law and ensures the correct implementation of the rules by a through systematic monitoring. The infringement procedure is used by the EU Commission whenever the Commission considers that an EU country has not incorporated a directive into national law correctly. This way, Commission ensures that all the rights set out in the directives are available in national law. Still, the Commission can't procure redeeming for individual citizens (i.e. compensate damages or set a situation right) this can be done only by the competent national authorities.

With over 240 million workers in the European Union, EU labor law rights benefit directly a large numbers of citizens and have a tremendous positive impact on one of the most important and tangible areas of their daily lives.

EU labor law also benefits employers and society as a whole by: providing a clear framework of rights and obligations in the workplace; protecting the health of the workforce; promoting sustainable economic growth.

Furthermore, EU labor law goes hand in hand with the single market. The free flow of goods, services, capital and, not at least, workers needs to be accompanied by labor law rules, that ensures fair competition between countries and businesses based on the strength of their products and not on lowering labor law standards.

\section{EU Labor law principles}

Fair treatment means equal opportunities and is a basic right in the European Union. This mean that is illegal to discriminate because of a person's sex, age, disability, ethnic or racial origin, religion, belief or sexual orientation.

Laws for equal rights between women and men have existed since the very early days of the European Community and since 1970s a total of 13 pieces of legislation have been adopted with the aim of ensuring women and men fair and equal treatment at work.

These laws cover a range of areas including equal treatment when apply for a job, equal treatment at work, protection of pregnant workers and breastfeeding mothers, and rights to maternity leave and parental leave.

Sex discrimination is not the only discrimination form and in 2000 the new EU legislation prohibits to discriminate against someone because of their:

- Racial and ethnic origin

- Religion and belief

- Disability

- Sexual orientation

- Age 
These five areas of discrimination, together with gender discrimination, are included in the Amsterdam Treaty of the European Union as areas where the EU can act to prevent discrimination.

Of course discrimination can occur for other reasons, such as because a person marital statute (is married or not), because of their income level, because of where they live. Discrimination can also happen because of a mix of different reasons, such as someone's age and their sex (for instance an older woman might be particularly vulnerable to unfair treatment in the jobs market).

The laws to protect people against discrimination because of their racial and ethnic origin (for example their black skin color or their Roma origin) cover not only employment but other areas of daily life where unfair treatment can occur, such as in schools, housing, health care or access to good and services, such unfair treatment in shops, restaurants, hotels etc.

All countries in the EU are obliged to take these equality rules on board. Countries joining the EU also have to comply with these rules.

EU equal treatment legislation sets out minimum levels of protection that apply to everyone living and working in the European Union. Countries can go further and adopt even stronger legal measures.

\section{Flexicurity in EU}

Legislation is vital in the fight for equality but nowadays EU needs to do more. This is why the European Union is supporting a range of measures to combat discrimination, from funding projects, to carrying out research to supporting awareness-raising and information campaigns.

Flexicurity is an integrated strategy for enhancing, simultaneously, flexibility and security in the labor market. It attempts to reconcile employers' need for a flexible workforce with workers' need for security - confidence that they will not face long periods of unemployment.

Common principles of flexicurity mean working with national governments, social partners in order to determine how countries can implement them through four components:1. flexible and reliable contractual arrangements, 2. comprehensive lifelong learning strategies, 3. effective active labor market policies, 4. modern social security systems

Flexicurity is a main component for the Employment Guidelines and also the European Employment Strategy as a whole. Integrated flexicurity policies play a major role in modernizing labor markets and contributing to the achievement of the $75 \%$ employment rate targeted by the Europe 2020 Strategy.

Measures initiated regarding this issue include:

- Agenda for new jobs skills: for reducing segmentation and supporting transitions by strengthening the flexicurity components and implementation; equipping people with the right skills for employment, improving job quality and the working conditions, and supporting job creation

- New skills for new jobs: for upgrading, anticipating and better matching skills and jobs

- Youth on the Move: to help young people acquire skills, qualifications and experience

- $\quad$ anticipating, preparing and managing company restructuring

- $\quad$ strengthening public employment services (for example job search support, career analyses, validation of experience, and so on). 
Policymakers continue to face the challenge of fighting Europe's high unemployment levels and devising policies that will help on building a dynamic and resilient labor market.

\section{Conclusions}

Employment levels in the EU have begun to rise again, and the economies worst affected by the crisis: Greece, Ireland, Portugal and Spain have shown employment growth in the last 12 months. However, wide divergence in labor market performance is still obvious across Member States, with unemployment rates ranging from below $5 \%$ (in Austria) to nearly 26\% (in Greece). Eurofound's European Monitoring Centre on Change (EMCC) tracks change in labor markets. The EMCC operates the European Restructuring Monitor (ERM) to track major restructuring events and enable analysis of trends across Member States and sectors. This shows that while employment in some sectors, especially manufacturing and construction, has been very strongly hit, others, as ICT and professional services, have continued to create jobs. The annual report from the ERM describes the latest trends in restructuring, and major restructuring news is reported regularly in the ERM quarterly. Restructuring not only affects the company and its employees but can have a major impact on the region where the company is based.

Competitive growth in Europe is based on finding the right balance of economic activities. It is important to distinguish between cyclical job loss and the structural loss of jobs (in some manufacturing sectors, for instance), which will not be recovered when Europe pulls out of crisis. Employment has shown a pattern of polarization over the past years, having greatest growth in top-paying and low-paying jobs and muted growth in the middle of the pay spectrum jobs. This polarization was more intense during the crisis, with the large job losses in manufacturing and construction. The resilient jobs have tended to be in knowledge-intensive services in both the public sector (such as health and education sectors) as well as in the private sector.

Jobs in Europe are growing in quality, but the greatest challenge remains to have enough jobs. To ensure that social support systems remain viable as Europe's population ages, it is crucial that more people are employed and that employees stay employed for longer over their lifetimes. These goals can be achieved only if workers are healthy, qualified and motivated to stay employed for longer and if the wider societal supports are in place to enable people to stay employed. Sustainable employment covers the many areas of ensuring that people are able and available to work; quality of work is a central theme, as are policies supporting work and employment.

\section{References}

Decision (EU) 2016/344 of the European Parliament and of the Council of 9 March 2016 on establishing a European Platform to enhance cooperation in tackling undeclared work available at eur-lex.europa.eu/legalcontent/EN/TXT/?uri=CELEX:32016D0344

Council recommendation of 15 February 2016 on the integration of the long-term unemployed into the labour market Document 32016H0220(01) available at eur-lex.europa.eu > ... > EU law and publications > EUR-Lex

Opinion of the European Economic and Social Committee on the Annual Growth Survey 2016 (COM(2015) 690 final) and the 'Draft Joint Employment Report accompanying the Communication from the Commission on the 
Annual Growth Survey 2016' (COM(2015) 700 final available at ec.europa.eu/europe2020/.../2016/ags2016_annual_growth_.

European Parliament resolution of 4 July 2013 on the European Parliament's priorities for the Commission Work Programmer 2014 (2013/2679(RSP))

European employment strategy of European Commission COM/2012/0173 final */ available at eurofound.europa.eu/news/spotlight-on/employment/overviewemployment-jobs-in-europe

Nimineţ, Liviana, (2015), A humanizing economic approach on competition policy or how the behavioral economics blends with "traditional economics", Studies and scientific researches. Economic edition, Issue 21, pp 32-37 